OPEN ACCESS

Edited by:

Frank Edgar Muller-Karger University of South Florida,

United States

Reviewed by:

Luis Lizcano-Sandoval, University of South Florida,

United States

Inés Mazarrasa,

Environmental Hydraulics Institute

(IHCantabria), Spain

${ }^{*}$ Correspondence:

Kenji Sudo

ksudo.hokudai@gmail.com

Specialty section:

This article was submitted to

Marine Conservation

and Sustainability,

a section of the journal

Frontiers in Marine Science

Received: 04 December 2020

Accepted: 31 May 2021

Published: 08 July 2021

Citation:

Sudo K, Quiros TEAL, Prathep A,

Luong CV, Lin H-J, Bujang JS,

Ooi JLS, Fortes MD, Zakaria MH,

Yaakub SM, Tan YM, Huang $X$ and

Nakaoka M (2021) Distribution,

Temporal Change, and Conservation

Status of Tropical Seagrass Beds

in Southeast Asia: 2000-2020.

Front. Mar. Sci. 8:637722.

doi: 10.3389/fmars.2021.637722

\title{
Distribution, Temporal Change, and Conservation Status of Tropical Seagrass Beds in Southeast Asia: 2000-2020
}

\author{
Kenji Sudo ${ }^{1 *}$, T. E. Angela L. Quiros ${ }^{1}$, Anchana Prathep ${ }^{2}$, Cao Van Luong ${ }^{3}$, \\ Hsing-Juh Lin ${ }^{4,5}$, Japar Sidik Bujang ${ }^{6}$, Jillian Lean Sim Ooi ${ }^{7}$, Miguel D. Fortes, \\ Muta Harah Zakaria ${ }^{9,10}$, Siti Maryam Yaakub ${ }^{11}$, Yi Mei Tan ${ }^{12}$, Xiaoping Huang ${ }^{13}$ and \\ Masahiro Nakaoka
}

\begin{abstract}
${ }^{1}$ Akkeshi Marine Station, Field Science Center for Northern Biosphere, Hokkaido University, Hokkaido, Japan, ${ }^{2}$ Seaweed and Seagrass Research Unit, Excellence Centre for Biodiversity of Peninsular Thailand, Division of Biological Science, Faculty of Science, Prince of Songkla University, Hat Yai, Thailand, ${ }^{3}$ Institute of Marine Environment and Resources, Vietnam Academy of Science and Technology, Hai Phong, Vietnam, ${ }^{4}$ Department of Life Sciences, National Chung Hsing University, Taichung, Taiwan, ${ }^{5}$ Innovation and Development Center of Sustainable Agriculture, National Chung Hsing University, Taichung, Taiwan, ${ }^{6}$ Department of Biology, Faculty of Science, Universiti Putra Malaysia, Serdang, Malaysia, ${ }^{7}$ Department of Geography, Faculty of Arts and Social Sciences, Universiti Malaya, Kuala Lumpur, Malaysia, ${ }^{8}$ Marine Science Institute CS, University of the Philippines, Quezon, Philippines, ${ }^{9}$ Department of Aquaculture, Faculty of Agriculture, Universiti Putra Malaysia, Serdang, Malaysia, ${ }^{10}$ The International Institute of Aquaculture and Aquatic Sciences, Port Dickson, Malaysia, ${ }^{11}$ DHI Water \& Environment (S) Pte Ltd., Singapore, Singapore, ${ }^{12}$ Centre for Integrative Ecology, School of Life and Environmental Sciences, Deakin University, Geelong, VIC, Australia, ${ }^{13}$ Key Laboratory of Tropical Marine Bio-Resources and Ecology, South China Sea Institute of Oceanology, Chinese Academy of Sciences, Guangzhou, China
\end{abstract}

Although Southeast Asia is a hotspot of global seagrass diversity, there are considerable information gaps in the distribution of seagrass beds. Broad-scale seagrass distribution has not been updated in the global seagrass database by UNEP-WCMC since 2000, although studies on seagrasses have been undertaken intensively in each region. Here we analyze the recent distribution of tropical seagrass beds, their temporal changes, causes of decline and conservation status in Southeast Asia (plus southern mainland China, Taiwan and Ryukyu Island of Japan) using data collected after 2000. Based on the 195 literature published since 2000, we identified 1,259 point data and 1,461 polygon data showing the distribution of seagrass beds. A large discrepancy was found in the seagrass bed distribution between our updated data and the UNEPWCMC database, mostly due to inaccurate and low resolution location information in the latter. Temporal changes in seagrass bed area analyzed for 68 sites in nine countries/regions demonstrated that more than $60 \%$ of seagrass beds declined at an average rate of $10.9 \%$ year $^{-1}$, whereas $20 \%$ of beds increased at an average rate of $8.1 \%$ year $^{-1}$, leading to an overall average decline of $4.7 \%$ year $^{-1}$. Various types of human-induced threats were reported as causes for the decline, including coastal development, fisheries/aquaculture, and natural factors such as typhoons and tsunamis. The percentage of seagrass beds covered with existing marine protected areas (MPAs) varied greatly among countries/regions, from less than $1 \%$ in Brunei Darussalam and Singapore to $100 \%$ in southern Japan. However, the degree of 
conservation regulation was not sufficient even in regions with higher MPA coverage. The percentage of seagrass beds within EBSAs (Ecologically and Biologically Significant Area determined by the Convention of Biological Diversity) was higher than that within MPAs because EBSAs cover a greater area than MPAs. Therefore, designating EBSAs as legally effective MPAs can greatly improve the conservation status of seagrass beds in Southeast Asia.

\section{Keywords: broad-scale distribution, coastal ecosystem, GIS mapping, marine protected area, temporal trend}

\section{INTRODUCTION}

Seagrass beds consist of marine flowering plants and are one of the most important habitats in the coastal ecosystem of the world (Hemminga and Duarte, 2000; Short et al., 2007). Seagrass beds support numerous flora and fauna, including endangered and commercially important species (Kikuchi and Peres, 1977; Williams and Heck, 2001; Nakaoka, 2005). They provide many valuable ecosystem services to humans, such as seafood provision (Unsworth et al., 2019), water quality control (Nakaoka et al., 2014; Lamb et al., 2017), disaster resilience (Duarte et al., 2013), blue carbon stock (Fourqurean et al., 2012), disease control, climate regulation, and tourism (United Nations Environment Programme [UNEP], 2020). The total economic value of seagrass ecosystem services per area exceeds that of terrestrial ecosystems such as forests (Costanza et al., 1997, 2014; Dewsbury et al., 2016). Costanza et al. (2014) estimated values of seagrass/algae beds were $\$ 28,916 \mathrm{ha}^{-1} \mathrm{year}^{-1}$, while values of tropical forests were $\$ 5,382 \mathrm{ha}^{-1}$ year $^{-1}$.

Seagrass beds have been threatened by various types of human-induced stressors, including eutrophication, coastal development, and global climate change (Orth et al., 2006; Waycott et al., 2009; Japar Sidik et al., 2018; Muta Harah et al., 2019). Such multiple human-induced impacts cause rapid loss and deterioration of this important coastal habitat. Waycott et al. (2009) estimated that seagrass beds were disappearing at a rate of $7 \%$ year $^{-1}$ globally. However, their data did not contain those from Southeast Asia, where seagrass diversity is the highest in the world (Green and Short, 2003). The estimated global decline of seagrass beds may have been underestimated due to a lack of long-term quantitative scientific data from this region. Thus, it is urgently needed to collect more data and compile already existing data on the distribution of seagrass beds, and to conduct analyses of their recent status and temporal trends for promoting their effective conservation and management.

International efforts of seagrass researchers to understand the status of seagrass beds of the world have been continuing since the 1990s (Green and Short, 2003). One of the outputs is the global map of seagrass published as the "World Atlas of Seagrass" (Green and Short, 2003). The geographic information system (GIS) data on this map have been available from the database "Global Distribution of Seagrasses" (GDS) by UNEP$\mathrm{WCMC}^{1}$. Developed countries in North America, Europe, and Australia have frequently updated data on seagrass beds after

${ }^{1}$ http://data.unep-wcmc.org/ (accessed on September 2020).
2003. In contrast, they have not been updated for most Asian countries since 2001. Furthermore, the GIS data from these countries were mostly based on low-resolution spatial data with low accuracy. For example, some GDS data in Thailand was mapped at the resolution of maximum $10 \mathrm{~km}$ along the coast, which lead to an estimate 10 times larger than the area estimated by conducted by diving surveys (Department of Marine and Coastal Resources, 2012). Furthermore, some GDS points in Vietnam occurred 10-30 km offshore from the coastline, which is too deep for seagrass beds to occur. This may be ascribed to inaccurate GPS coordinates.

With the increasing awareness of the importance of seagrass beds in the coastal ecosystems of Southeast Asia, the amount of research by scientists and governmental managers to monitor and study seagrass beds has been increasing since the beginning of this century (e.g., Nakaoka et al., 2014). The accuracy of mapping seagrass distribution has also improved with the development of novel GIS and remote sensing techniques (Luong et al., 2012; Hossain et al., 2015; Chen et al., 2016; Koedsin et al., 2016; Huong et al., 2017). The development of a robust networked system of seagrass observations has recently been initiated (Duffy et al., 2019) including archiving of open-access data. However, most new data collected by local researchers and managers in Asia have been reported in their local literature (mostly in their native languages), which precludes more frequent updates to the global database. The situation ultimately limits planning effective conservation and management by decision makers based on the most recent information. Fortes et al. (2018) reviewed the distribution, extent, species diversity, and knowledge gaps of seagrasses in Southeast Asia, although they only presented summary data for each country with precise spatial information lacking in some regions.

The aim of this paper is to report the distribution of seagrass beds between 2000 and 2020, their temporal changes, and protection status in Southeast Asia, based on up-to-date information. To achieve this goal, we compiled data on seagrass beds published since 2000 . We first analyzed the distribution of tropical seagrass beds in 13 countries/regions and compared them with the global database by GDS (version 6 in UNEPWCMC and Short, 2018). Second, we analyzed temporal changes in areal distribution of seagrass beds. Finally, we examined the conservation status of these seagrass beds with marine protected areas (MPAs), and with Ecologically or Biologically Significant Marine Areas (EBSAs) that are candidates of future MPAs designated by the Convention on Biological Diversity ${ }^{2}$

\footnotetext{
${ }^{2}$ https://www.cbd.int/ebsa/
} 
(Convention on Biological Diversity, 2010; Yamakita et al., 2017). The obtained results from our study will contribute to updating the global map of seagrass, and to facilitate effective management of seagrass habitat and associated marine biodiversity in Southeast Asia.

\section{MATERIALS AND METHODS}

\section{Study Site}

This study targeted the tropical region of Southeast Asia spanning 10 countries: Brunei Darussalam, Cambodia, TimorLeste, Indonesia, Malaysia, Myanmar, Philippines, Singapore, Thailand, and Vietnam. We also included subtropical regions in southern mainland China, Taiwan, and the Ryukyu Islands of Japan. The northern boundary was set so that it covered the northern limit of tropical seagrass species; i.e., Fujian Province in China $\left(26^{\circ} \mathrm{N}\right)$, Taiwan $\left(26^{\circ} \mathrm{N}\right)$, and the southern part of Kagoshima in Japan $\left(31^{\circ} \mathrm{N}\right.$ ) (Zheng et al., 2013; Environment Agency and Marine Parks Center of Japan, 1994).

\section{Data Collection}

We searched literature available online (peer-reviewed/non-peerreviewed scientific papers, and reports) using the terms "seagrass" and target country/region name (e.g., "Brunei Darussalam") through Web of Science, Google Scholar, and Google. From reference lists of collected literature, we also carried out a secondary survey for literature written in local languages. Some of these local literatures were available only as hard copies stored in offices and libraries of research institutions. We obtained these information as well as other sources by requesting them from researchers and governmental officials in these institutions. In total, we compiled more than 195 scientific papers and reports published after 2000. The data collected by 2018 were published as a data paper (Sudo and Nakaoka, 2020). In this paper, we added 88 literature and 719 data published by 2020 that was not included in the data paper (Supplementary Table 1). From these literatures, we obtained a total of 2,720 data on the distribution of seagrass beds (Supplementary Tables 1, 2).

\section{Data Analyses}

The compiled seagrass bed distribution data were georeferenced using the ArcGIS georeference tool and classified into two formats to make the GIS database; point data $(n=1,259)$ and polygon data $(n=1,461)$. When seagrass meadow cartography was presented (such as a map in figures), we compiled it as a polygon datum by remapping manually from the published resource. When it was not available, we only used the record of the seagrass bed site information as a point datum. For each datum, areas of seagrass beds were recorded if given in the literature. Among 1,259 point data, 228 had area information written directly in the paper without further spatial information. Original data sources of 1,461 polygon data (from 42 literature) varied greatly. Among the 16 literature that used satellite images for areal estimation, 13 applied low-resolution products such as Landsats 5-8, ALOS (Advanced Land Observing Satellite), Sentinel 2 and SPOT 5 (Système Pour l'Observation de la Terre 5) (ca $30 \mathrm{~m} /$ pixel resolution), whereas three literature applied more fine-resolution WorldView-2 imagery (ca $0.5 \mathrm{~m} /$ pixel resolution). Area estimation for the other polygon data were based on in situ field surveys (22 literature) and aerial photographs (two literature). The original sources of area estimation are given in our database (Supplementary Table 1). If the seagrass bed area was not available in the original sources, we directly calculated the area by GIS from the polygon data.

Temporal changes in seagrass bed area were analyzed for all the seagrass beds with multiple data (at least two data points), separated by at least 2 years. A total of 68 seagrass beds had such temporal data; 29 in Vietnam, 17 in Thailand, 11 in mainland China, 6 in Malaysia, 2 in the Ryukyu Islands, and one in Singapore, the Philippines, and Taiwan (Supplementary Table 3). The data taken before 2000 was included for this analysis if the area was estimated by the same method in each literature (see Supplementary Table 3). Among the 68 seagrass beds, 54 had only two data, two had three data, and 12 had more than 4 data for estimating trends in seagrass area cover. The rate of seagrass bed distribution change $\left(\mu, \%\right.$ year $\left.^{-1}\right)$ for each seagrass bed was calculated over a time interval, $t$, from the initial to final reported areas $\left(\mathrm{A}_{o}\right.$ and $\mathrm{A}_{t}$, respectively) as $\mu=\ln \left(\mathrm{A}_{t} / \mathrm{A}_{o}\right) / \mathrm{t} \times 100$ (Waycott et al., 2009). We calculated the overall trend in $\mu$ as the median and mean rate of change, and standard errors (SEs). To avoid possible variation due to seasonal change, we used data on the same month or season if there were more than three temporal data and the month/season was known. According to Waycott et al. (2009), we defined seagrass bed area as increasing/declining when there was more than a $10 \%$ change in area detected between the initial and final time periods, whereas we defined no change if the change was less than $10 \%$. The seagrass beds that had seriously declined during the monitoring period (with an area estimate of 0 in the final time, but seagrasses still present in a patchy manner) were excluded from the calculation of percentage rate of change (Waycott et al., 2009).

Threats against seagrass beds were recorded if the information was available. They were classified into the following 10 categories; coastal development (e.g., port construction, dredging, reclamation, etc.), sedimentation, aquaculture, destructive fishing, water quality (pollution), mangrove plantation, tourism, shipping, tsunami, and other natural factors.

The conservation status of seagrass beds in each country/region was analyzed by calculating the area of seagrass protected inside MPAs and EBSAs. The area of MPAs was obtained from Protected Planet (UNEP-WCMC and IUCN, $2020)^{3}$. For each MPA, the degree of protection level was classified following the IUCN protected areas categories as follows; Strict nature reserve (Ia), Wilderness area (Ib), National park (II), Natural monument or feature (III), Habitat/species management area (IV), Protected landscape/seascape/area (V), and Protected area with sustainable use of natural resources (VI) (Day et al., 2012; see Supplementary Table 4). In short, regulation is stricter with a lower category number. We obtained spatial data on EBSAs from the Clearing-House Mechanism of the Convention on Biological Diversity Information Submission

\footnotetext{
${ }^{3}$ https://www.protectedplanet.net/marine (accessed September 11, 2020).
} 
Services (Convention on Biological Diversity, 2018) ${ }^{4}$. EBSAs consist of coastal, pelagic and deep-sea areas. In this study we only used the coastal EBSAs for the analysis. The percentage of seagrass beds covered by MPAs and EBSAs was calculated as follows. For countries/regions which only have polygon data, the overlap between the area of seagrass beds and MPAs/EBSAs were directly calculated using GIS. For those only with point data, the number of point data found within each MPA or EBSA was counted and expressed as a percentage of the total number of seagrass point data in that particular country/region. For those with both point and polygon data, polygon data were first converted to point data by extracting the center of gravity. Then, the same calculation was made as in those only with point data.

\section{RESULTS}

\section{Seagrass Bed Distribution}

We mapped the distribution of 2,720 seagrass beds present between 2000 and 2020 in Figure 1A. Seagrass bed distribution data from the GDS collected before 2001 is shown in Figure 1B. Seagrass beds are present along most coastlines of our study areas. Regions with very few seagrass beds are also found in these two databases, such as in the southern part of Vietnam, the middle part of Myanmar, northern and southern Sumatra Island, the southeast part of Borneo Island and coastline of West Papua facing Arafura Sea (Figure 1).

The area of seagrass beds greatly differed between our database and GDS. Large discrepancies were found in some countries/regions in Vietnam, Myanmar, Cambodia, and Taiwan, whereas overlap is better for the Philippines, Singapore, and southern mainland China (Supplementary Figure 5). In the case of Vietnam, point data by GDS was located far offshore (deeper than $20 \mathrm{~m}$ sea bottom) compared to those used in our study. Distribution of seagrass beds in Myanmar by GDS data did not totally overlap with our data. In Cambodia and Taiwan, our database had more seagrass beds than GDS, and only one seagrass bed overlapped in both databases for each country/region.

\section{Temporal Changes in Seagrass Bed Area and Their Causes}

Temporal changes were assessed for 68 seagrass beds in eight countries/regions, in which data from southern mainland China, Vietnam, and Thailand are dominant, but the time-series data were not available for any seagrass bed in Indonesia, Cambodia, Myanmar, Brunei Darussalam, Timor-Leste, and Indonesia. Forty-four sites (64.7\%) experienced decline with the mean rate of $10.9 \pm 2.6 \%$ year $^{-1}$. Ten sites $(14.7 \%)$ showed no detectable change and 14 sites (20.6\%) showed an increase in seagrass bed size with a mean rate of $8.1 \pm 2.2 \%$ year $^{-1}$ (Table 1). Overall, the mean percentage rate of change of all the seagrass beds (excluding the seven seriously-declined beds) was $-4.7 \pm 2.0 \%$ year $^{-1}$. Median rate of change was somewhat smaller than mean in absolute values (Table 1). The declining beds were mostly located in the southern mainland China, Vietnam, but also found

\footnotetext{
${ }^{4}$ https://chm.cbd.int/database (accessed February 17, 2018).
}

in the Ryukyu Islands, the Philippines, Thailand, Malaysia, and Singapore (Figure 2). Beds with the increasing area were mostly found in Thailand and some in Vietnam.

Among the human-induced stressors, seagrass bed decline was mostly caused by coastal development, followed by aquaculture activities, destructive fishing, and water quality deterioration (Table 2). Tourism, shipping, and mangrove plantation were also reported as causes for the decline. Coastal development as a cause for the decline was reported from all countries/regions, and aquaculture from southern mainland China, Philippines, and Vietnam such as shrimp pond and fish cage. Destructive fishing was reported from southern mainland China, Philippines and Vietnam. In Thailand, threats against seagrass beds were classified as destructive fishing (6 cases), sedimentation (5), development (3), and aquaculture (2).

Natural factors such as large typhoons caused decline in seagrass beds in 16 sites. The tsunami caused by the 2004 Indian Ocean earthquake was a declining factor in Thailand (three sites).

\section{Protection Status}

The percentage of seagrass beds located within existing MPAs and EBSAs varied greatly among countries/regions (Table 3). Among 4 countries/regions which have seagrass bed polygon data over their whole coastal area, more than $99 \%$ of seagrass beds are within MPAs in Ryukyu Islands of Japan, 50\% in TimorLeste, 33\% in Indonesia, 20\% in Thailand, and 13\% in Cambodia. For countries/regions estimated by point data, more than $50 \%$ of seagrass beds are within MPAs in Taiwan and Vietnam, 43\% in Myanmar, 15\% in Malaysia, 9\% in the Philippines, and only 6\% in the southern mainland China (Table 3). Seagrass beds in Singapore and Brunei Darussalam were not covered by MPAs.

Among different categories of MPAs, only a small proportion of seagrass beds in Cambodia, Indonesia and Malaysia are included in the categories Ia and Ib (strict nature reserve and wilderness) (Table 3). Up to $43 \%$ of seagrass beds are included in the categories II (national parks), whereas those covered by the categories IV, V, and VI (habitat/species management area, protected landscape/seascape, and protected area with sustainable use of natural resources) are small except Ryukyu Islands (Table 3). Seagrass beds are not covered with the category III (natural monument or feature). Protection categories are not specified for $>30 \%$ of seagrass beds in MPAs for Indonesia, Timor-Leste, and Vietnam (Table 3).

The proportion of seagrass beds in EBSAs greatly varies among countries/regions (Table 3). More than 50\% of seagrass beds are within EBSAs for the Ryukyu Islands, Singapore, and Malaysia, whereas less than $10 \%$ for Cambodia, Vietnam, Indonesia, and southern mainland China. No seagrass beds are covered with EBSAs for Brunei Darussalam and Taiwan because EBSAs have not been set for these countries/regions.

\section{DISCUSSION}

The present study updated the seagrass bed distribution in Southeast Asia where information in the global seagrass database had been stagnant. GIS analyses revealed large differences in the 

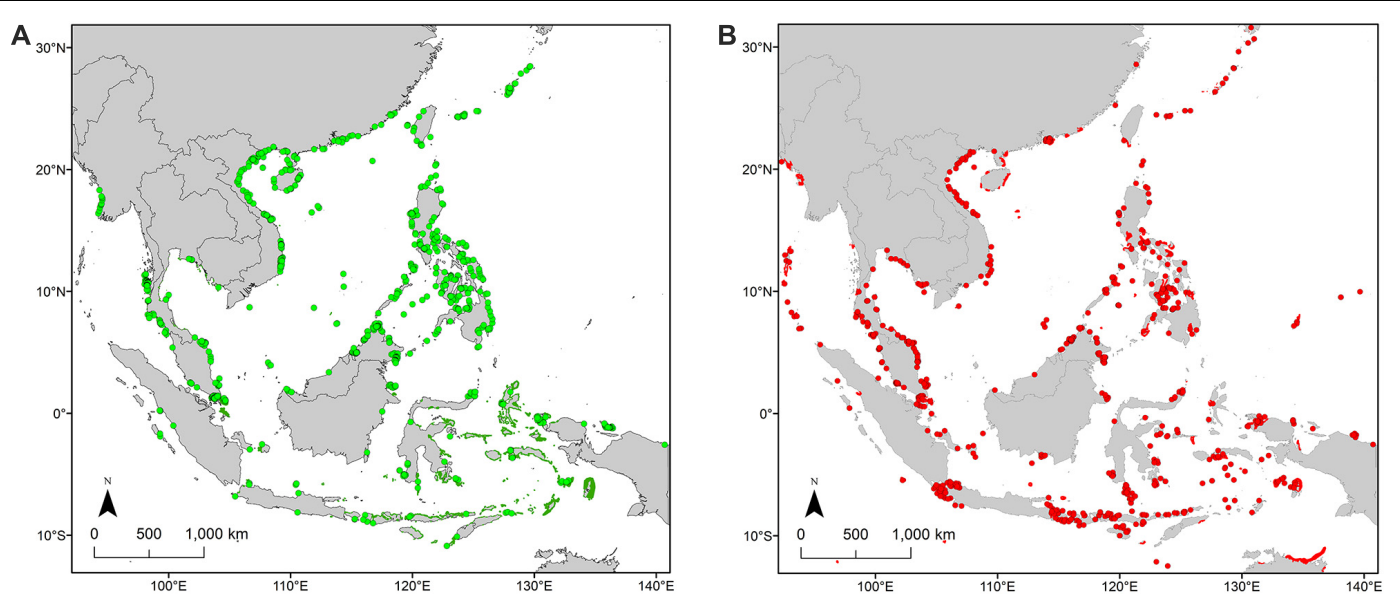

FIGURE 1 | Seagrass beds distribution in Southeast Asia based on (A) the data compiled in this study (2000-2020) and (B) Global Distribution of Seagrass ver. 6.0 which is the collection of data taken before 2001.

TABLE 1 | Percentage rate of change for seagrass beds.

\begin{tabular}{lcccc}
\hline & Proportion in category (\%) & \multicolumn{2}{c}{ Mean\% rate of change } & \multicolumn{1}{c}{ Median\% rate of change } \\
\cline { 3 - 5 } & & $\boldsymbol{\mu}$ & $\mathbf{N}$ & $\boldsymbol{\mu}$ \\
\hline Declining & 64.7 & -10.9 & 2.6 & -6.9 \\
Increasing & 20.6 & 8.1 & 2.2 & 4.9 \\
No detectable change & 14.7 & 0.0 & 0.1 & 0.0 \\
Overall & 100 & -4.7 & 2.0 & -2.5 \\
\hline
\end{tabular}

location and area of seagrass beds compared with the GDS data collected before 2001. Analyses of temporal changes in seagrass bed size revealed that more than half of the seagrass beds are declining in most regions, and that seagrass beds located inside MPAs were less than $50 \%$.

\section{Comparison of the Updated GIS Data With Previous Information}

Our study compiled seagrass bed distribution data along the whole coastline of Southeast Asia. Compared to the GDS data, our study dramatically increased the information from Cambodia, Thailand, Timor-Leste, Singapore, Vietnam, southern mainland China, and the Ryukyu Islands of Japan. Before our data updates, Brunei Darussalam had no reports, and Myanmar and Taiwan had very few data. On the other hand, large regional gaps in seagrass bed information remain in the Philippines and Indonesia, which was also pointed out by a recent global estimation on seagrass bed distribution (McKenzie et al., 2020). In these regions, ongoing projects are trying to map habitats including seagrass beds and mangroves by satellite and lidar analysis (Republic of the Philippines, 2019), but as they are not yet open to the public, we did not use them in this paper.

We found great discrepancies in the areas of seagrass beds between the GDS information collected before 2001 and our updated data. The discrepancies could be due to either (1) the change (increase or decrease) in seagrass beds, (2) new discoveries in the previously unsurveyed areas, or (3) low accuracy and low resolution in the data. Due to the second and third reasons, it is not plausible to examine long-term changes in seagrass bed areas by comparing data across the databases.

Low accuracy in the previous data can likely explain most discrepancies. For example, GDS seagrass beds in Vietnam occur far offshore from the coastline (Supplementary Figure 5). Water depth here is deeper than $20 \mathrm{~m}$, which exceeds the major distributional zone of seagrass beds. Similar biases in seagrass bed distribution due to inaccurate GPS information were also found in Malaysia and Indonesia. Too coarse resolution of the previous GIS data is another source for the discrepancy among databases. For example, seagrass beds in Ranong, Phuket and Krabi Provinces in Thailand extend more than $5 \mathrm{~km}$ from the coastline in the GDS due to its coarse grain size. Actual distribution in these sites were less than $500 \mathrm{~m}$ from the coastline based on more recent analyses by the Thailand Government (Department of Marine and Coastal Resources, 2018) ${ }^{5,6}$, which is included in our database.

GIS-based image analyses of whole coastal areas using satellite images improved the seagrass bed distribution mapping, which had been difficult to estimate only by field surveys. In our dataset however, most of the satellite images were Landsat and similar satellite products, which had too low resolution for accurate discrimination of seagrass beds. Our database also contains area estimates for the point data where the area is written only

\footnotetext{
${ }^{5}$ http://marinegiscenter.dmcr.go.th/gis (accessed April 9, 2018).

${ }^{6}$ https://datacenter.dmcr.go.th/ (accessed April 2, 2021).
} 


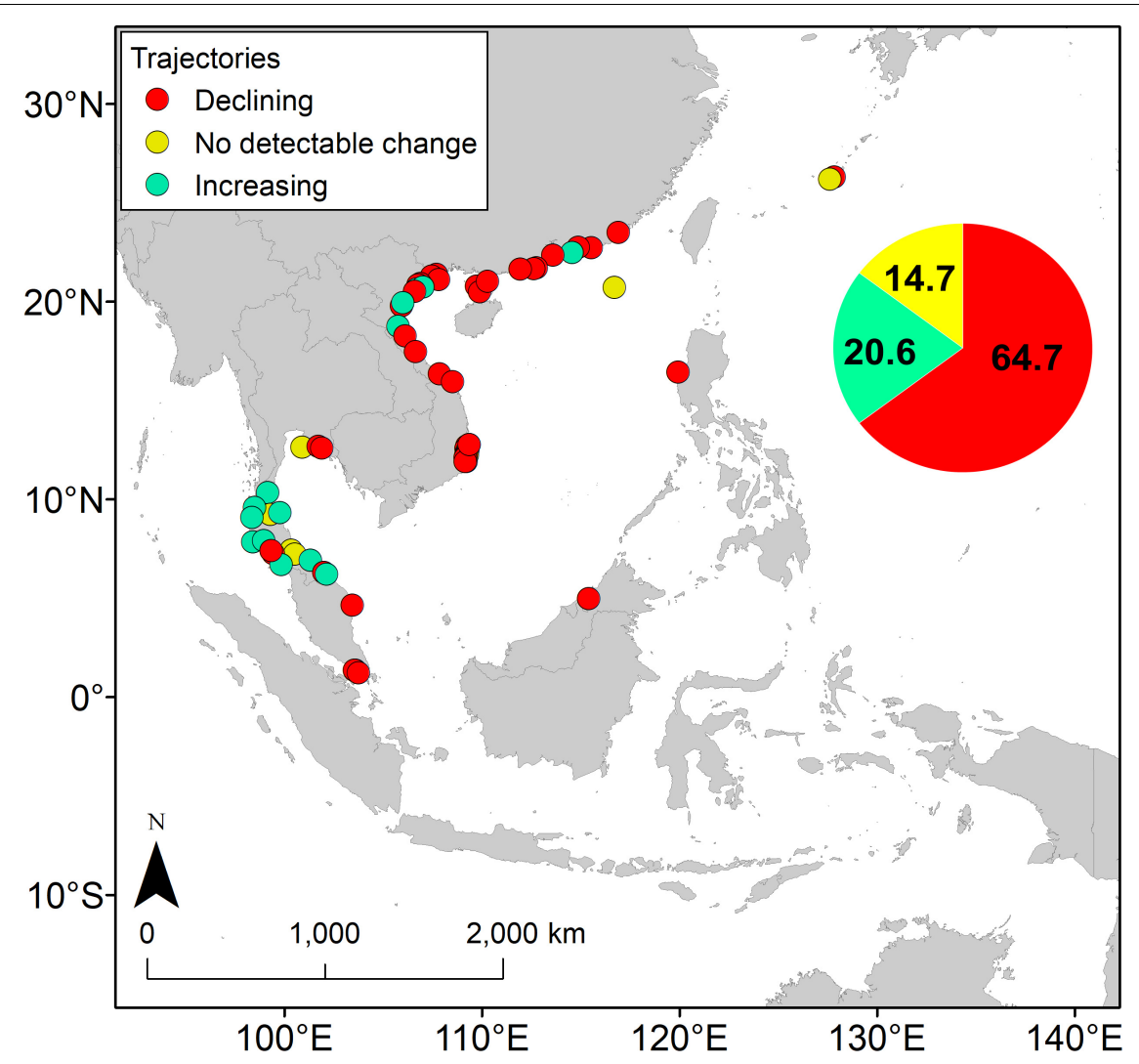

FIGURE 2 | Trajectories of seagrass beds in the Southeast Asia.

TABLE 2 | The number of literature (peer-reviewed/non-peer-reviewed scientific papers and reports) reporting drivers that were responsible for the decline of seagrass beds.

\begin{tabular}{|c|c|c|c|c|c|c|c|c|}
\hline & $\mathbf{R I J}$ & SMC & MYS & PHL & SGP & THA & VNM & Total \\
\hline Coastal development & 2 & 4 & 3 & & 1 & 6 & 3 & 19 \\
\hline Sedimentation & & & & & & 2 & 3 & 6 \\
\hline Aquaculture & & 6 & & 1 & & 2 & 6 & 14 \\
\hline Destructive fishing & & 1 & & & & 6 & 3 & 10 \\
\hline Water quality & & 3 & & & 1 & 2 & 3 & 8 \\
\hline Tourism & & 1 & & & & 1 & 2 & 4 \\
\hline Shipping & & & & & 1 & & 2 & 3 \\
\hline Mangrove plantation & & 1 & & & & & 0 & 1 \\
\hline Tsunami & & & & & & 2 & 1 & 3 \\
\hline Natural factor & 1 & & 3 & & & 10 & 2 & 16 \\
\hline
\end{tabular}

RIJ, Ryukyu Island of Japan; SMC, Southern mainland China; MYS, Malaysia; PHL, Philippines; THA, Thailand; VNM, Vietnam.

in the text without explicate spatial information, so evaluation of accuracy was not possible. On the other hand, the massive effort of diving surveys in Cambodia, Thailand, and Taiwan highly improved accuracy in seagrass bed distribution estimation. Seagrass bed distribution in southern mainland China has also been reviewed and updated (Zheng et al., 2013; Jiang et al., 2020). All these efforts have led to more precise information on seagrass bed distribution in Southeast Asia.

Both our study and the GDS detected very few seagrass beds in some coastlines over several hundred kilometers. These regions likely lack seagrass beds due to unsuitable habitat. Seagrass beds rarely develop on too muddy bottoms covered with turbid water, which may explain their absence in southern Vietnam and the central coast of Myanmar where great deltas are created by major river inputs of the Mekong and Irrawaddy, respectively. Likewise, coastlines of the northeast and south Borneo are dominated by mangroves and generally too sedimentary for seagrass beds. However, surveys may not be sufficiently conducted in some areas to understand overall seagrass bed distribution in Southeast Asia. More frequent data input and updates are required, 


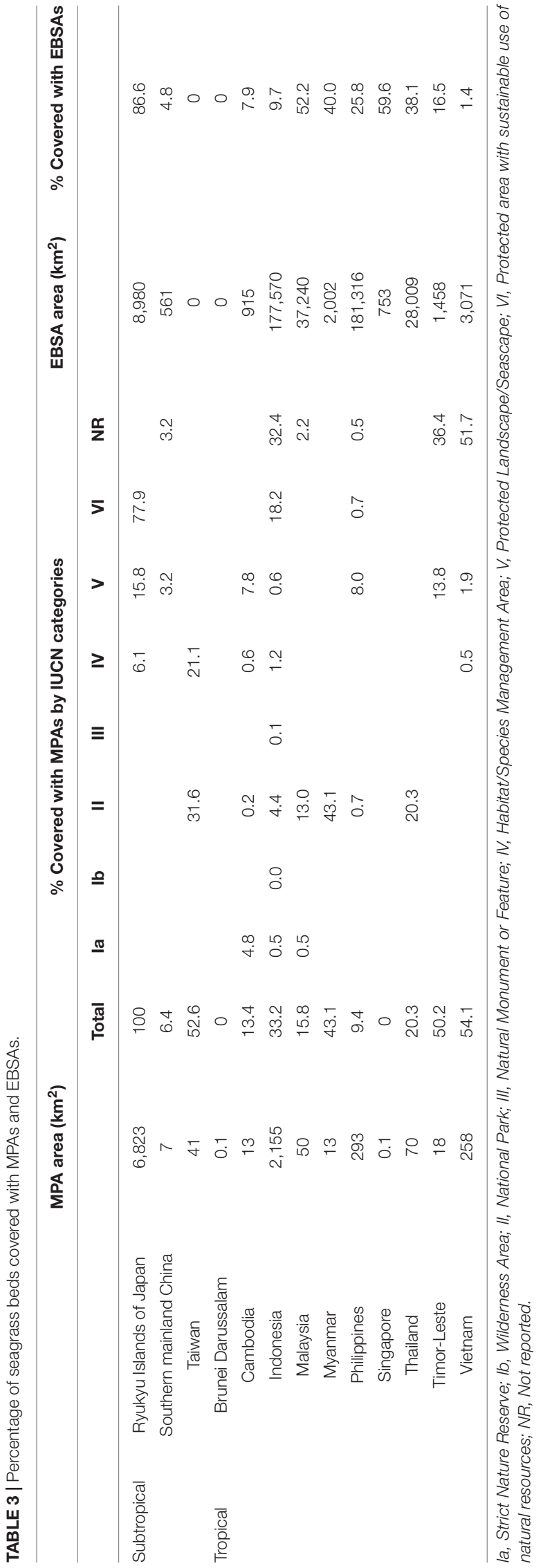

especially for some key countries such as Indonesia, Malaysia, and the Philippines.

The data summarized for each country/region can be compared with the GDS and that of Fortes et al. (2018), where seagrass distribution data up to 2017 were used for 10 Southeast Asian countries (Table 4). Our data showed that Indonesia has the greatest seagrass bed area $\left(2,934.6 \mathrm{~km}^{2}\right)$, followed by Cambodia, Thailand, and Vietnam $\left(>150 \mathrm{~km}^{2}\right)$ although information on seagrass bed area was very scarce for the Philippines (Table 3). The estimated bed area was smaller than that of the GDS for all regions. The area estimated by our survey is less than 1\% of the GDS for Myanmar and southern mainland China, and less than 10\% for Taiwan, Malaysia, Philippines, Singapore, and Timor-Leste (Table 4). The differences are mostly due to overestimation of the GDS seagrass bed area due to low resolution images, as discussed earlier. In contrast, the estimates of seagrass bed area in most countries in our study are in close agreement with those reported by Fortes et al. (2018) because the two studies share many of the same original data sources. However, the addition of ca. 2,500 new data in our study increased the seagrass bed extent for Malaysia, Singapore, and Thailand, even within the short time difference between the two studies. In Cambodia, our estimate becomes smaller than Fortes et al. (2018) because we used more accurate data provided later by the Cambodian Government (Supkong and Bourne, 2014). However, our estimates are much smaller for the Philippines and Indonesia than Fortes et al. (2018) because the criteria for including data to our dataset are more strict (only published data taken on and after 2000).

\section{Temporal Changes in Seagrass Beds and Their Causes}

To examine temporal changes in seagrass beds, we avoided using data from multiple sources due to large biases among different databases as mentioned above. This resulted in a relatively small amount of data on temporal change ( $n=68$ meadows), and the data are spatially biased toward some countries like Vietnam and Thailand. Furthermore, most of these data had only two data points which may not reflect actual patterns of temporal fluctuation. Nevertheless, it contributes to information on the changes of seagrass beds, which were not included in the previous global assessment of seagrass beds (Waycott et al., 2009).

The percentage of declining seagrass beds $(65 \%)$ was higher than that reported globally (58\%) and that of Zostera marina in Europe (57\%). Furthermore, the mean decline rate $(11 \%$ year $^{-1}$ ) was 1.6 times greater than the global average of $6.9 \%$ year $^{-1}$ and higher than the $9.5 \%$ year $^{-1}$ decline in Europe (Waycott et al., 2009; de los Santos et al., 2019). Our estimate seems reasonable considering the high economic growth rate of Southeast Asia, where the majority of people live along the coastal area (Neumann et al., 2015).

We observed geographical variation in the patterns of temporal change. More seagrass beds are declining in Vietnam and southern mainland China, whereas most seagrass beds are stable or even increasing along the coast of Thailand. The increase in many Thailand seagrass beds may be explained by the fact 
TABLE 4 | Comparison of areal extent of seagrass beds $\left(\mathrm{km}^{2}\right)$ by countries/regions.

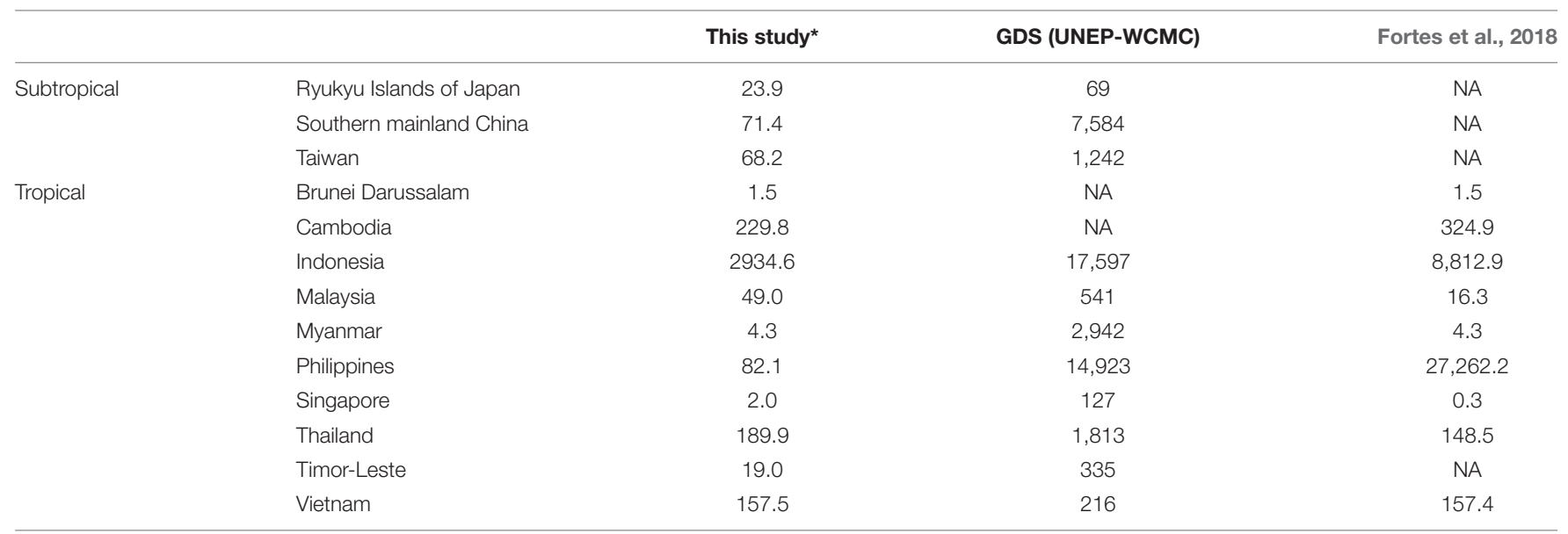

*Methods of estimation is given in Supplementary Table 1 (Sheet "5 Remarks").

that these data were collected after 2004 when the Andaman Sea Coast was hit by the 2004 Indian Ocean Earthquake and Tsunami. The tsunami heavily affected some seagrass beds in this region (Adulyanukosol and Poovachiranon, 2006; Whanpetch et al., 2010). The increase in seagrass beds in this region may reflect a natural recovery from the catastrophic disturbance. In contrast, decline in southern mainland China and Vietnam may be ascribed to coastal development, which reflects active economic development in these regions (Luong et al., 2012; Jiang et al., 2020). The data on temporal change in seagrass beds are still very scarce in other counties and regions, which preclude the general evaluation of seagrass bed trends in the whole Southeast Asia.

Various types of threats have been reported as causes for the decline or loss of seagrass beds around the world, such as coastal development, sedimentation, dredging, degraded water quality, and climate changes (Orth et al., 2006; Waycott et al., 2009; Japar Sidik et al., 2018; Muta Harah et al., 2019). In Europe, water quality degradation, wasting disease, coastal modification, mechanical damage, extreme events, and non-native macroalgae invasion was recently reported as major factors related to seagrass bed change (de los Santos et al., 2019). In our study, development, aquaculture and destructive fishing were reported as major anthropogenic factors for seagrass bed decline in Southeast Asia, which agrees with previous studies reviewing the status of seagrass beds in this region (Luong et al., 2012; Nakaoka et al., 2014; Chen et al., 2016; Fortes et al., 2018; Japar Sidik et al., 2018).

In addition to anthropogenic factors, it is worth to mention that natural factors such as floods, typhoons, tsunamis and El Niño-Southern Oscillation (ENSO) were reported as major causes for seagrass bed declines in this region (Adulyanukosol and Poovachiranon, 2006; Nakaoka et al., 2007; Whanpetch et al., 2010; Luong et al., 2012; Japar Sidik et al., 2018; Lin et al., 2018; Vo et al., 2020). For the typhoon damage however, it may also be related to human activities because of the recent storm intensification with ongoing climate change. Another unique case we found as cause of decline are mangrove plantations, which suggests that improper restoration efforts without sound scientific knowledge can lead to deterioration of coastal ecosystems (Primavera and Esteban, 2008; Sharma et al., 2017; Mendoza et al., 2019).

\section{Conservation Status of Seagrass Beds}

Marine protected areas can protect coastal ecosystems and resident organisms from various human activities such as coastal development and overexploitation (Short and WyllieEcheverria, 1996). Our analysis showed that percentage of seagrass beds within the existing MPAs are highly variable among countries/regions. Almost all the tropical seagrass beds are within MPAs in the Ryukyu Islands. In contrast, MPAs protect no seagrass beds in Singapore and Brunei Darussalam. However, even within MPAs, regulation levels for conservation also vary, which can be evaluated using the IUCN protected area management categories (Dudley, 2008). The categories Ia (strict nature reserve) and $\mathrm{Ib}$ (wilderness area) are considered highly effective to protect seagrass beds, but very few sites are in these categories. The category II (national parks) is also effective in preventing seagrass beds from coastal development and aquaculture activities, and less than $45 \%$ of seagrass beds in our study area are covered under this category. In contrast, a greater percentage of seagrass beds are covered by the categories $\mathrm{V}$ and VI, which allow fishing and aquaculture activities (Day et al., 2012), and thus have less conservation impact on seagrass beds and their biodiversity.

The Aichi Target of the CBD declared to protect more than $10 \%$ of the coastal and marine areas inside MPAs by 2020 , and the CBD is preparing more ambitious targets to increase protected areas by 2030 (Convention on Biological Diversity, 2020). To attain these goals, EBSAs were determined as candidates for future MPAs (Dunn et al., 2014; Yamakita et al., 2017). Because the coverage of EBSAs is broader than most MPAs (see Table 3), the percentage of seagrass beds located within EBSAs is higher than that inside MPAs, except for Brunei Darussalam and Taiwan, which do not have any EBSAs. This indicates that efforts to designate EBSAs as legally effective MPAs to meet CBD 
targets will be promising to improve the conservation status of seagrass beds and to prevent further loss of seagrass beds in Southeast Asia.

\section{CONCLUSION}

This study clarified the recent distribution of tropical seagrass beds, their temporal changes and conservation status based on the updated information taken on and after 2000 in Southeast Asia, where information has been scattered among local literature. We found large differences in the estimation of seagrass bed areas between our updated information and the previous version of the seagrass database by GDS, which is mostly ascribed to inaccurate information and many remaining gaps. We also found that more than $60 \%$ of seagrass beds declined at an average rate of $11 \%$ year $^{-1}$, whereas $20 \%$ of beds increased at an average rate of $8 \%$ year $^{-1}$, leading to an overall average decline of $5 \%$ year $^{-1}$. The proportion of seagrass beds included in MPAs is high in some countries/regions, although the level of actual regulation for conservation was not sufficient. Our updated information is still insufficient to understand the overall status of seagrass beds in Southeast Asia and more data input is required for some key countries such as Indonesia, Malaysia and the Philippines. Nevertheless, our fine-resolution, broad-scale information will contribute to updating global information on seagrass beds and facilitate effective conservation and management of seagrass beds in the Southeast Asia region, which is still under great threat by multiple human-induced stresses. Included in these stressors are unsound policies emanating from the failure of governments to link science, policy and practice (Fortes, 2018).

\section{DATA AVAILABILITY STATEMENT}

The original contributions presented in the study are included in the article/Supplementary Material, further inquiries can be directed to the corresponding author.

\section{AUTHOR CONTRIBUTIONS}

$\mathrm{KS}$, TQ, and MN conceived the research, analyzed the data, and wrote the manuscript. AP, CL, H-JL, JB, JO, MF, MZ, SMY, YT,

\section{REFERENCES}

Adulyanukosol, K., and Poovachiranon, S. (2006). "Dugong (Dugong dugon) and seagrass in Thailand: present status and future challenges," in Proceedings of the 3rd International Symposium on SEASTAR2000 and Asian Bio-Logging Science (The 7th SEASTAR2000 Workshop) Graduate School of Informatics, (Kyoto: Kyoto University), 41-50.

Chen, C. F., Lau, V. K., Chang, N. B., Son, N. T., and Chiang, S. H. (2016). Multi-temporal change detection of seagrass beds using integrated Landsat TM/ETM+/OLI imageries in Cam Ranh Bay. Vietnam. Ecol. Inform. 35, 43-54. doi: 10.1016/j.ecoinf.2016.07.005

Convention on Biological Diversity (2010). Decision adopted by the Conference of the Parties to the Convention on Biological Diversity at its Tenth Meeting (UNEP/CBD/COP/DEC/X/29). Rio de Janeiro: Convention on Biological Diversity, and $\mathrm{XH}$ provided seagrass beds information and contributed to improve the quality of the manuscript. All authors contributed to the article and approved the submitted version.

\section{FUNDING}

This study was supported by Environment Research and Technology Development Funds by Environmental Restoration and Conservation Agency, Japan (S-15: Predicting and Assessing Natural Capital and Ecosystem Services), the Belmont Forum fund by Japan Science and Technology Agency (TSUNAGARI), SATPREPS program by Japan Science and Technology AgencyJapan International Cooperation Agency (BlueCARES), Japan Society of the Promotion of Science-Kakenhi (No. 20KK0246), Core-to-Core Program by Japan Society for the Promotion of Science Program, B. Asia-Africa Science Platforms, project with coded 03/HD-SKHCN, and Vietnam Academy of Science and Technology project (VAST06.06/21-22).

\section{ACKNOWLEDGMENTS}

This manuscript is a contribution to the Asia-Pacific Marine Biodiversity Observation Network (AP-MBON) of the Group on Earth Observations Biodiversity Observation Network (GEO $\mathrm{BON})$. We are grateful to the members of Phuket Marine Biological Center in Thailand and the Vietnam Academy of Science and Technology for providing local literature and data on seagrass bed distribution. This paper is dedicated to Chittima Aryuthaka who contributed greatly to the development of marine biology and ecology in Asia during her lifetime.

\section{SUPPLEMENTARY MATERIAL}

The Supplementary Material for this article can be found online at: https://www.frontiersin.org/articles/10.3389/fmars. 2021.637722/full\#supplementary-material

Convention on Biological Diversity (2018). Clearing-House Mechanism of the Convention on Biological Diversity Information Submission Services. Available online at: https://chm.cbd.int/database (accessed February 17, 2018).

Convention on Biological Diversity (2020). Update of the Zero Draft of the Post-2020 Global Biodiversity Framework (CBD/POST2020/PREP/2/1). Rio de Janeiro: Convention on Biological Diversity.

Costanza, R., d'Arge, R., De Groot, R., Farber, S., Grasso, M., Hannon, B., et al. (1997). The value of the world's ecosystem services and natural capital. Nature 387, 253-260. doi: 10.1038/387253a0

Costanza, R., De Groot, R., Sutton, P., Van der Ploeg, S., Anderson, S. J., Kubiszewski, I., et al. (2014). Changes in the global value of ecosystem services. Glob. Environ. Change 26, 152-158. doi: 10.1016/j.gloenvcha.2014. 04.002

Day, J., Dudley, N., Hockings, M., Holmes, G., Laffoley, D. D. A., Stolton, S., et al. (2012). Guidelines for Applying the IUCN Protected Area Management 
Categories to Marine Protected Areas. Available online at: https://portals.iucn. org/library/node/10201 (accessed September 22, 2018).

de los Santos, C. B., Krause-Jensen, D., Alcoverro, T., Marbà, N., Duarte, C. M., van Katwijk, M. M., et al. (2019). Recent trend reversal for declining European seagrass meadows. Nat. Comm. 10:3356. doi: 10.1038/s41467-019-11340-4

Department of Marine and Coastal Resources (2012). Status of Seagrass in Thailand. Available online at: https://km.dmcr.go.th/en/c_4/d_775 (accessed March 31, 2021).

Department of Marine and Coastal Resources (2018). Thailand Central Database System and Data Standard for Marine and Coastal Resources. Available online at: http://marinegiscenter.dmcr.go.th/gis https://datacenter.dmcr.go.th/ (accessed April 9, 2018).

Dewsbury, B. M., Bhat, M., and Fourqurean, J. W. (2016). A review of seagrass economic valuations: gaps and progress in valuation approaches. Ecosyst. Serv. 18, 68-77. doi: 10.1016/j.ecoser.2016.02.010

Duarte, C. M., Kennedy, H., Marbà, N., and Hendriks, I. (2013). Assessing the capacity of seagrass meadows for carbon burial: current limitations and future strategies. Ocean Coast. Manag. 83, 32-38. doi: 10.1016/j.ocecoaman.2011.09. 001

Dudley, N. (2008). Guidelines for Applying Protected Area Management Categories. Gland, Switzerland: IUCN. $x+86 p p$. WITH Stolton, S., Shadie P. and Dudley N. (2013). IUCN WCPA Best Practice Guidance on Recognising Protected Areas and Assigning Management Categories and Governance Types, Best Practice Protected Area Guidelines Series No. 21. Gland: IUCN, 31.

Duffy, J. E., Benedetti-Cecchi, L., Trinanes, J., Muller-Karger, F. E., Ambo-Rappe, R., Boström, C., et al. (2019). Toward a Coordinated global observing system for seagrasses and marine macroalgae. Front. Mar. Sci. 6:317. doi: 10.3389/fmars. 2019.00317

Dunn, D. C., Ardron, J., Bax, N., Bernal, P., Cleary, J., Cresswell, I., et al. (2014). The convention on biological diversity's ecologically or biologically significant areas: origins, development, and current status. Mar. Policy 49, 137-145. doi: 10.1016/j.marpol.2013.12.002

Environment Agency and Marine Parks Center of Japan (1994). The Report of the Marine Biotic Environment Survey in the 4th National Survey on the Natural Environment. Algal and Sea-Grass Beds.

Fortes, M. D. (2018). Seagrass ecosystem conservation in Southeast Asia needs to link science to policy and practice. Ocean Coast. Manag. 159, 51-56.

Fortes, M. D., Ooi, J. L. S., Tan, Y. M., Prathep, A., Bujang, J. S., and Yaakub, S. M. (2018). Seagrass in Southeast Asia: a review of status and knowledge gaps, and a road map for conservation. Botanica Marina 61, 269-288. doi: 10.1515/bot-2018-0008

Fourqurean, J. W., Duarte, C. M., Kennedy, H., Marbà, N., Holmer, M., Mateo, M. A., et al. (2012). Seagrass ecosystems as a globally significant carbon stock. Nat. Geosci. 5, 505-509. doi: 10.1038/ngeo1477

Green, E. P., and Short, F. (2003). World atlas of seagrasses. Prepared by the UIMEP World Conservation Monitoring Centre. Berkeley, CL: University of California Press.

Hemminga, M. A., and Duarte, C. M. (2000). Seagrass Ecology. Cambridge: Cambridge University Press, 312.

Hossain, M. S., Japar Sidik, B., Muta Harah, Z., and Hashim, M. (2015). Application of landsat images to seagrass areal cover change analysis for Lawas, Terengganu and Kelantan of Malaysia. Cont. Shelf Res. 110, 124-148. doi: 10.1016/j.csr.2015. 10.009

Huong, N. T. T., Tuan, T. A., Thach, V. T., and Tin, H. C. (2017). A review of seagrass studies by using satellite remote sensing data in the southeast asia: status and potential. Vietnam J. Sci. Technol. 55:148.

Japar Sidik, B., Muta Harah, Z., and Short, F. T. (2018). "Seagrass in Malaysia: issues and challenges," in The Wetland Book II: Distribution, Description and Conservation, eds C. Max Finlayson, G. Randy Milton, R. Crawford Prentice, and N. C. Davidson (Berlin: Springer), 1875-18839. doi: 10.1007/s13280-0100067-7

Jiang, Z., Cui, L., Liu, S., Zhao, C., Wu, Y., Chen, Q., et al. (2020). Historical changes in seagrass beds in a rapidly urbanizing area of Guangdong province: implications for conservation and management. Glob. Ecol. Conserv. 22:e01035. doi: 10.1016/j.gecco.2020.e01035

Kikuchi, T., and Peres, J. M. (1977). "Consumer ecology of seagrass beds," in Seagrass Ecosystems: A Scientific Perspective, eds C. P. McRoy and C. Helfferich (New York, NY: Marcel Dekker Inc.).
Koedsin, W., Intararuang, W., Ritchie, R. J., and Huete, A. (2016). An integrated field and remote sensing method for mapping seagrass species, cover, and biomass in southern Thailand. Remote Sens. 8:292.

Lamb, J. B., van de Water, J. A. J. M., Bourne, D. G., Altier, C., Hein, M. Y., Fiorenza, E. A., et al. (2017). Seagrass ecosystems reduce exposure to bacterial pathogens of humans, fishes, and invertebrates. Science 355, 731-733. doi: 10.1126/science. aal1956

Lin, H. J., Lee, C. L., Peng, S. E., Hung, M. C., Liu, P. J., and Mayfield, A. B. (2018). The effects of El Niño-Southern Oscillation events on intertidal seagrass beds over a long-term timescale. Glob. Change Biol. 24, 4566-4580. doi: 10.1111/gcb. 14404

Luong, C. V., Van Thao, N., Komatsu, T., Ve, N. D., and Tien, D. D. (2012). "Status and threats on seagrass beds using GIS in Vietnam," in Proceedings of the Remote Sensing of the Marine Environment II, Vol. 8525, (Bellingham: International Society for Optics and Photonics), 852512. doi: 10.1117/12.977277

McKenzie, L., Nordlund, L. M., Jones, B. L., Cullen-Unsworth, L. C., Roelfsema, C. M., and Unsworth, R. (2020). The global distribution of seagrass meadows. Environ. Res. Lett. 15:074041. doi: 10.1088/1748-9326/ab7d06

Mendoza, A. R. R., Patalinghug, J. M. R., and Divinagracia, J. Y. (2019). The benefit of one cannot replace the other: seagrass and mangrove ecosystems at Santa Fe, Bantayan Island. J. Ecol. Environ. 43:18. doi: 10.1186/s41610-019-0114-7

Muta Harah, Z., Japar Sidik, B., Syed, N. N. F., Ramaiya, S. D., Emmclan, S. S. H. E., and Hayashizaki, K. (2019). Macroalgae associated with Tanjung Adang Laut seagrass meadow, Sungai Pulai estuary, Johor, Malaysia, from 2015 to 2017. Phil. J. of Nat. Sci. 24, 66-79.

Nakaoka, M. (2005). Plant-animal interactions in seagrass beds: ongoing and future challenges for understanding population and community dynamics. Popul. Ecol. 47, 167-177.

Nakaoka, M., Lee, K.-S., Huang, X., Almonte, T., Bujang, J., Kiswara, W., et al. (2014). "Regional comparison of the ecosystem services from seagrass beds in Asia," in Integrative Observations and Assessments. Ecological Research Monographs, eds S. Nakano, T. Yahara, and T. Nakashizuka (Tokyo: Springer), doi: 10.1007/978-4-431-54783-9_20

Nakaoka, M., Tanaka, Y., Mukai, H., Suzuki, T., and Aryuthaka, C. (2007). Tsunami Impacts on Biodiversity of Seagrass Communities in the Andaman Sea, Thailand:(1) Seagrass Abundance and Diversity. Kyoto: Kyoto University.

Neumann, B., Vafeidis, A. T., Zimmermann, J., and Nicholls, R. J. (2015). Future coastal population growth and exposure to sea-level rise and coastal flooding-a global assessment. PLoS One 10:e0118571. doi: 10.1371/journal.pone.0118571

Orth, R. J., Carruthers, T. J., Dennison, W. C., Duarte, C. M., Fourqurean, J. W., Heck, K. L., et al. (2006). A global crisis for seagrass ecosystems. Bioscience 56, 987-996.

Primavera, J. H., and Esteban, J. M. A. (2008). A review of mangrove rehabilitation in the Philippines: successes, failures and future prospects. Wetl. Ecol. Manag. 16, 345-358. doi: 10.1007/s11273-008-9101-y

Republic of the Philippines (2019). 6th National Report for the Convention on Biological Diversity. Available online at: https://chm.cbd.int/database/record/ 9D0D456A-FAC1-9806-3B90-21B37D4DEE5B (accessed April 2, 2020).

Sharma, S., Nadaoka, K., Nakaoka, M., Uy, W. H., MacKenzie, R. A., Friess, D. A., et al. (2017). Growth performance and structure of a mangrove afforestation project on a former seagrass bed, Mindanao Island, Philippines. Hydrobiologia 803, 359-371. doi: 10.1007/s10750-017-3252-x

Short, F. T., Carruthers, T., Dennison, W., and Waycott, M. (2007). Global seagrass distribution and diversity: a bioregional model. J. Exp. Mar. Biol. Ecol. 350, 3-20. doi: 10.1016/j.jembe.2007.06.012

Short, F. T., and Wyllie-Echeverria, S. (1996). Natural and human-induced disturbance of seagrasses. Environ. Conserv. 27, $17-27$.

Sudo, K., and Nakaoka, M. (2020). Fine-scale distribution of tropical seagrass beds in Southeast Asia. Ecol. Res. 35, 994-1000. doi: 10.1111/1440-1703. 12137

Supkong, P., and Bourne, L. (2014). A Survey of Seagrass Beds in Kampot, Cambodia. Thailand: IUCN, 91.

UNEP-WCMC and IUCN (2020). Marine Protected Planet: [The World Database on Protected Areas (WDPA)]. Cambridge: UNEP-WCMC.

UNEP-WCMC and Short, F. T. (2018). Global Distribution of Seagrasses (version 6.0). Sixth Update to the Data Layer used in Green and Short (2003). Cambridge: UN Environment World Conservation Monitoring Centre. 
United Nations Environment Programme [UNEP] (2020). Out of the Blue: The Value of Seagrasses to the Environment and to People. Nairobi: UNEP.

Unsworth, R. K., Nordlund, L. M., and Cullen-Unsworth, L. C. (2019). Seagrass meadows support global fisheries production. Conserv. Lett. 12:e12566. doi: $10.1111 /$ conl.12566

Vo, T. T., Lau, K., Liao, L. M., and Nguyen, X. V. (2020). Satellite image analysis reveals changes in seagrass beds at Van Phong Bay, Vietnam during the last 30 years. Aquat. Living Resour. 33:4. doi: 10.1051/alr/2020005

Waycott, M., Duarte, C. M., Carruthers, T. J. B., Orth, R. J., Dennison, W. C., Olyarnik, S., et al. (2009). Accelerating loss of seagrasses across the globe threatens coastal ecosystems. Proc. Natl. Acad. Sci. U.S.A. 106, 12377-12381. doi: 10.1073/pnas.0905620106

Whanpetch, N., Nakaoka, M., Mukai, H., Suzuki, T., Nojima, S., Kawai, T., et al. (2010). Temporal changes in benthic communities of seagrass beds impacted by a tsunami in the Andaman Sea, Thailand. Estuar. Coast. Shelf Sci. 87, 246-252. doi: 10.1016/j.ecss.2010.01.001

Williams, S. L., and Heck, K. L. Jr. (2001). Seagrass community ecology," in Marine Community Ecology eds M. D. Bertness, S. D. Gaines, and M. E. Hay (Sunderland, MA: Sinauer Associates, Inc), 317-337.

Yamakita, T., Sudo, K., Jintsu-Uchifune, Y., Yamamoto, H., and Shirayama, Y. (2017). Identification of important marine areas using ecologically or biologically significant areas (EBSAs) criteria in the East to Southeast Asia region and comparison with existing registered areas for the purpose of conservation. Mar. Pol. 81, 273-284. doi: 10.1016/j.marpol.2017.03.040

Zheng, F., Qiu, G., Fan, H., and Zhang, W. (2013). Diversity, distribution and conservation of Chinese seagrass species. Biodivers. Sci. 21, 517-526. doi: 10. 3724/SP.J.1003.2013.10038

Conflict of Interest: SMY was employed by the company DHI Water \& Environment (S) Pte Ltd.

The remaining authors declare that the research was conducted in the absence of any commercial or financial relationships that could be construed as a potential conflict of interest.

Copyright $\odot 2021$ Sudo, Quiros, Prathep, Luong, Lin, Bujang, Ooi, Fortes, Zakaria, Yaakub, Tan, Huang and Nakaoka. This is an open-access article distributed under the terms of the Creative Commons Attribution License (CC BY). The use, distribution or reproduction in other forums is permitted, provided the original author(s) and the copyright owner(s) are credited and that the original publication in this journal is cited, in accordance with accepted academic practice. No use, distribution or reproduction is permitted which does not comply with these terms. 